\title{
A hypothesis for explaining the geographical distribution of Crohn's disease
}

\author{
Cyrus P TAMBOLI BSc
}

CP TAMBOLI. A hypothesis for explaining the geographical distribution of Crohn's disease. Can J Gastroenterol 1996; 10(3):173177. The etiology of Crohn's disease (CD) remains unknown, although there is epidemiological evidence supporting an environmental influence. Recent molecular techniques, including polymerase chain reaction, have renewed interest in a possible etiological role of Mycobacterium paratuberculosis, which has been isolated from a number of $\mathrm{CD}$ patients. The organism causes a chronic enteritis in animals called paratuberculosis, a condition with many clinical and pathological similarities to CD. This review compares the epidemiology of paratuberculosis in animals with the epidemiology of CD in humans. There is considerable overlap of regions with high prevalences of paratuberculosis and CD. This finding adds support to the implication of M paratuberculosis in the etiology of CD.

Key Words: Crohn's disease, Epidemiology, Etiology, Mycobacterium paratuberculosis

\section{Hypothèse sur la distribution géographique de la maladie de Crohn}

RÉSUMÉ : L'étiologie de la maladie de Crohn demeure inconnue, bien que certaines données épidémiologiques soient indicatrices d'une influence environnementale. Les récentes techniques d'investigation moléculaires, y compris l'amplification génique, ont réveillé l'intérêt à l'endroit du rôle possible de Mycobacterium paratuberculosis, qui a été isolé chez plus d'un patient. L'organisme pathogène provoque chez l'animal une entérite chronique appelée paratuberculose, qui ressemble à plusieurs points de vue cliniques et pathologiques à la maladie de Crohn. Cette synthèse compare l'épidémiologie de la paratuberculose chez l'animal à celle de la maladie de Crohn chez l'humain. On note un chevauchement considérable des régions où les cas de paratuberculose et de maladie de Crohn sont nombreux. Cette observation appuie le rôle de M. paratuberculosis dans l'étiologie de la maladie de Crohn.
$\mathrm{C}$ rohn's disease $(\mathrm{CD})$ is an inflammatory bowel disease primarily affecting people in temperate zones. The etiology remains unknown, although it likely involves a combination of genetic and environmental influences. The hypothesis that Mycobacteriae may be involved in the etiopathogenesis of $\mathrm{CD}$ is not new. The role of Helicobacter pylori in peptic ulcer disease underscores the importance of searching for infectious agents in idiopathic gastrointestinal disorders $(1,2)$. Recently, several independent investigators (3) have isolated Mycobacterium paratuberculosis from CD patients. The organism is of particular interest because it causes a chronic, wasting enteritis in animals, mostly ruminants, which is called paratuberculosis or Johne's disease. Chiodini (4) has given a comprehensive historical and clinical comparison of $\mathrm{CD}$ and paratuberculosis. Molecular techniques such as polymerase chain reaction (PCR) have provided suggestive, albeit inconclusive, evidence that $M$ paratuberculosis may cause CD. Despite this growing body of evidence and in-

$\mathrm{Mr}$ Tamboli is a medical student at the University of Alberta (graduating class 1997)

Correspondence: Mr C Tamboli, Faculty of Medicine MD Program, 2-45 Medical Sciences Building, University of Alberta, Edmonton, Alberta T6G 2H7. Telephone 403-465-7359, fax 403-492-9531, e-mail ctamboli@gpu.srv.ualberta.ca

Received for publication September 11, 1995. Accepted November 20, 1995 
creased epidemiological literature concerning both diseases, few attempts have been made to record the similarity between the geographical distributions of the two diseases. This review compares such existing information. It furthers the hypothesis that $M$ paratuberculosis may cause $C D$ by showing that, in certain regions, large reservoirs of host animals susceptible to or infected by $M$ paratuberculosis exist close to urban regions having the highest $\mathrm{CD}$ prevalences. The mechanism by which infection may be transmitted from animals to humans may then be reasonably conjectured.

\section{EPIDEMIOLOGY OF CD}

Although CD has been reported in many countries, it is most prevalent in northern areas, particularly North America, Scandinavia and Great Britain $(5,6)$. The highest prevalence figures are from Edmonton, Alberta (7); Olmsted county, Minnesota (8); central and southwestern Sweden (9-11); Cardiff, Wales (12,13) and Aberdeen, Scotland (14). It is more prevalent in urban than rural inhabitants $(14-18)$, a feature that cannot be explained by migration patterns (17), but which may be due to the following features of urban areas: better access to medical care, exposure to other infections because of crowding conditions or exposure to possible contributing factors, eg, industrial pollution (18). The increasing incidence of $\mathrm{CD}$ in some areas over the past several decades suggests an environmental factor because the genetic makeup of humans is not expected to change so rapidly. CD may be more common in Caucasians (19). One study demonstrated an inverse correlation between CD prevalence and lactose intolerance (adult-onset) (20). Although milk has been long discounted as a possible cause of $\mathrm{CD}$, this correlation is interesting for reasons discussed later in this review.

\section{PARATUBERCULOSIS: IDENTIFICATION IN CD PATIENTS}

$\mathrm{M}$ paratuberculosis is a subspecies of the Mycobacterium avium complex (3). Although the $\mathrm{M}$ avium-intracellulare complex has been found in warm, watery environments $(21,22), M$ paratuberculosis has not yet been found as a freeliving organism. It may exist in a cell wall-deficient form that does not stain acid-fast $(4,23)$ and grows poorly, if at all, in culture $(4,21,24-26)$. Its DNA is $98 \%$ homologous with $M$ avium $(26,27)$, which is ubiquitous in the environment. Therefore, studies attempting cultural or serological identification of M paratuberculosis from CD patients may be fraught with difficulty. Recently, a genomic determinant unique to M paratuberculosis, called IS900, has been identified (28). By using PCR (the ultrasensitive technique of DNA amplification), IS900 has been used in studies of CD patients. PCR is ideally suited for detecting organisms in low numbers that grow slowly (29). The technique has been well described for identification of Mycobacteriae from standard pathological specimens (30). The main downfall of PCR is its exquisite sensitivity; this necessitates stringent laboratory technique to avoid false positive tests (31).

When unique genetic determinants are sought, serologi- cal (32) and PCR evidence (25,33-36) of M paratuberculosis has been found in up to $84 \%$ of CD patients. However, some investigators have not found $M$ paratuberculosis in $\mathrm{CD}$ tissue samples $(3,37,38)$, while others report finding $M$ paratuberculosis DNA in non-CD controls $(39,40)$. To date, it appears no PCR samples have been sent to a neutral third party for confirmation of PCR status.

\section{EPIDEMIOLOGY OF PARATUBERCULOSIS IN DOMESTIC AND WILD ANIMALS}

In 1895 paratuberculosis was first described in cattle. It is a chronic wasting granulomatous enteritis affecting mostly young animals, particularly ruminants such as domestic catthe and sheep, bighorn sheep, domestic and mountain goats, deer, moose, bison and others $(4,21,24,26,41-44)$. Crosscontamination of species may occur (24). Like CD, paratuberculosis has a similar maturity index, is characterized by relapse and remission, affects primarily the ileum (although any part of the gastrointestinal tract can be involved), and causes stricture formation, diarrhea and malnutrition. $\mathrm{M} \mathrm{pa-}$ ratuberculosis strains isolated from a CD patient have caused paratuberculosis when inoculated into goats (45). There is no cure for paratuberculosis and no adequate method to detect infected animals because the majority remain asymptomatic. The latency period may be up to 15 years in cattle, during which organisms may be shed fecally.

The complement-fixing antibody test has failed to detect serological evidence of exposure to $\mathrm{M}$ paratuberculosis in domestic cattle and sheep, and other free-ranging wild herbivores in Kenya (46). In animals testing positive (eight camels and one goat), cross-reaction with antibodies to a wide variety of organisms may have occurred $(21,46)$. In contrast, it has been estimated that $25 \%$ to $30 \%$ of all cattle in the United Kingdom are latently infected (47). The disease has an affinity for dairy cattle $(21,44,48,49)$.

Among domestic cattle, there appears to be a north to south gradient for paratuberculosis in the United States. In particular, the following American states have been recognized (43,44,48,50-52).

New England states: Connecticut, Massachusetts, New Jersey, New York, New Hampshire and Vermont collectively showed a prevalence of paratuberculosis in $18 \%$ of cattle from 100 culture specimens of slaughterhouse cattle (44).

Wisconsin: Eleven per cent of 1000 ileocecal valves from slaughterhouse samples cultured M paratuberculosis (52). This was considered an underestimate. Another study ranked Wisconsin fourth in overall prevalence (48).

Florida: Based on a serological study, 17\% of Florida cattle tested positive for paratuberculosis (51).

Pennsylvania and Minnesota: In one of the most recent surveys (48), 7540 ileocecal lymph nodes were cultured from apparently healthy slaughtered cattle from 32 states. Only Pennsylvania and Minnesota were significantly higher than the overall mean prevalence $(\mathrm{P}<0.01)$. The actual prevalences were probably underestimated due to methodology. 
Ohio: Ohio was ranked third overall in the study cited just above (48).

The rough distribution outlined here has been known for at least 20 years (50). It is unknown whether apparent increases in prevalence from 1949 to 1971 are real or due to better surveillance and diagnosis, although the latter is probably at least partially responsible.

Within Wisconsin, an uneven geographical distribution of paratuberculosis-infected dairy cattle herds exists $(43,53)$. The majority of infected cattle are found in the western, southern and southwestern portions of that state. This is interesting because Olmsted county, Minnesota (noted earlier for its unusually high CD prevalence) lies immediately adjacent to these areas. One small study from Alberta suggests that the prevalence of paratuberculosis in Alberta's domestic cattle is similar to the highest American figures (54).

The overlap of regions with paratuberculosis and CD becomes clearer when a study using national Medicare records of CD is considered. Using these records, Sonnenburg et al (55) defined the geographic distribution of $\mathrm{CD}$ in the United States for all persons aged 65 and older. Because Medicare is provided universally to this population, accessibility to medical care should not have influenced the results. Among Caucasians, the observed number of $\mathrm{CD}$ cases was higher than expected for 12 states. These states, in order of highest rate to lowest rate, are Massachusetts, Pennsylvania, New Jersey, New York, Florida, Ohio, Arizona, Michigan, Washington, Illinois, Connecticut and Maryland.

Comparison of the leading states for paratuberculosis and $\mathrm{CD}$ is noteworthy on two accounts. First, the overlap of the two lists is obvious. Second, Florida and Arizona appear as unique exceptions to the north to south gradient generally observable for both diseases. Sonnenburg and colleagues (55) suggest that Florida's climate may attract many northeastern retirees. Similarly, Arizona is a popular destination for many northwesterners. Therefore, the prevalence of CD in those states may be artificially inflated because the study population consisted only of persons aged 65 and over. The question of $\mathrm{CD}$ prevalence among young persons in these states is interesting, although presently unanswered.

Among wild animals, paratuberculosis has been reported in fallow deer and red deer in the United Kingdom (called elk in North America) (56-60), free-ranging bighorn sheep and Rocky Mountain goats in Colorado $(21,41,42)$, and moose (61). All these species are noteworthy because they occur in large numbers in the protected national parks of Alberta, which are close to Edmonton. Tuberculosis is prevalent in Alberta's wildlife; an epizootic of Mycobacterium bovis infection in domestic elk has likely infected humans (62). Located in northeastern Alberta, Wood Buffalo National Park is the only known reservoir of bovine tuberculosis and brucellosis in Canada, and the largest in North America $(63,64)$. Bison and elk in Elk Island National Park, $30 \mathrm{~km}$ east of Edmonton, have been previously infected with tuberculosis and brucellosis $(65,66)$. Paratuberculosis in Alberta's wildlife has not been investigated. The presence of one of the world's largest reservoirs of susceptible animals suggests that such investigation may be valuable, especially in light of the putative relationship of paratuberculosis to CD. Wild animals with paratuberculosis may be a reservoir of infection for domestic animals (67).

\section{DISCUSSION}

Interpreting the findings - A mechanism of infection: This review has compared existing data regarding $\mathrm{CD}$ and paratuberculosis. Similarities have been noted between their clinical and pathological characteristics and their geographic distribution, and there is direct evidence of $\mathrm{M}$ paratuberculosis presence in at least some CD patients. Despite this, several questions remain unanswered. Why does $\mathrm{CD}$ have an urban preponderance? What about CD patients far removed from large natural reservoirs of $\mathrm{M}$ paratuberculosis? If $\mathrm{M}$ paratuberculosis causes CD, how does it infect the individual? In a provocative editorial, Hermon-Taylor (68) forwarded the suggestion that $M$ paratuberculosis may cause $C D$, especially via ingestion of contaminated water or milk.

Heavy rains "will wash these organisms into the spate rivers" such as the Taff running into Cardiff, Wales, the Mississippi river on the Minnesota-Wisconsin border, the Dee river running into Aberdeen, Scotland or the North Saskatchewan river flowing through Edmonton, Alberta. In these regions, one can envision the large repositories of appropriate host animals - both domestic and wild - that reside upstream. Asymptomatically, the microorganisms are shed fecally and carried by the rivers into urban areas, where they are ingested with the drinking water. M paratuberculosis can survive for 163 days in river water, for 11 months in feces or soil and for at least 12 months at $-14^{\circ} \mathrm{C}(69,70)$. Mycobacterias, including the $\mathrm{M}$ avium complex, are commonly isolated from chlorinated municipal drinking tap waters, particularly in North America, the United Kingdom and Scandinavia $(71,72)$. There are no published studies that have specifically searched for M paratuberculosis from these sources. Consider the case of Edmonton, where CD is unusually prevalent. Its drinking water is obtained from the North Saskatchewan river. Research has shown that spring run-offs from creeks feeding the river carry livestock wastes to the city, periodically causing serious contamination of the raw water supply (73). Alberta has approximately 4800 cattle feedlots, and a large one can produce wastes equivalent to a city of 20,000 people. Correlations exist among peak creek and river runoff during the spring thaw, high river bacterial counts and raw water colour in Edmonton. Studies on water quality in Alberta suggest that information regarding the influence of agriculture on water quality is inadequate.

Alternatively, $M$ paratuberculosis may be able to survive pasteurization $(74,75)$ and so infect individuals, particularly through fluid milk. The distribution of dairy farms in Alberta is centred around Edmonton (76, personal communication). Of 11 milk marketing regions in Great Britain, South Wales has the greatest dependency on fluid milk production (77). Similarly, regions reporting the highest prevalences of CD correspond to the most area-intensive regions of dairy farming in the world (78). This may explain the correlation be- 
tween CD incidence and lactose-tolerant populations consuming large quantities of cow's milk (20). CD incidence has also been positively correlated with socioeconomic status (17). Among urban women, socioeconomic status is correlated with levels of fluid milk consumption (79). The risk of mycobacterial contamination of milk has been previously suspected (80).

\section{CONCLUSIONS}

Implications for future therapy: If CD is an infection, a cure is potentially available. Many studies have been conducted using antimycobacterial agents to treat $C D$, with varying success. Poor results may be due to small sample sizes, improper choice and/or duration of antibiotics, or incorrect diagnosis $(81,82)$. Clarithromycin, a new macrolide antibiotic, has one of the highest in vitro activities against $M$ paratuberculosis (83). Recent clinical experience suggests that clarithromycin may be useful for inducing remission in some CD patients (84). It may also play a role in the treatment of perianal fis-

ACKNOWLEDGEMENTS: The author acknowledges Drs EA Fanning, EA Ryan, ABR Thomson and EL Toth, Department of Medicine, University of Alberta, Edmonton, Alberta, for their assistance in reviewing the manuscript; and David Domes, Food Quality Branch, for providing data on Alberta dairy farm distribution.

\section{REFERENCES}

1. Thomson ABR, Williams CN. Helicobacter pylori: Basic mechanisms to clinical cure. Can J Gastroenterol 1995;9:91-5.

2. Walsh JH, Peterson WL. The treatment of Helicobacter pylori infection in the management of peptic ulcer disease. N Engl J Med 1995;333:984-91.

3. Thompson DE. The role of mycobacteria in Crohn's disease. J Med Microbiol 1994;41:74-94.

4. Chiodini RJ. Crohn's disease and the mycobacterioses: A review and comparison of two disease entities. Clin Microbiol Rev 1989;2:90-117.

5. Ekbom A, Adami HO. The epidemiology of inflammatory bowel disease. Curr Opin Gastroenterol 1991;7:649-53.

6. Jayanthi V, Probert CSJ, Mayberry JF. Epidemiology of inflammatory dowel disease. Q J Med 1991;78:5-12.

7. Pinchbeck BR, Kirdeikis J, Thomson ABR. Inflammatory bowel disease in northern Alberta. J Clin Gastroenterol 1988;10:505-15.

8. Gollop JH, Phillips SF, Melton LJ III, Zinsmeister AR. Epidemiologic aspects of Crohn's disease: a population based study in Olmsted County, Minnesota, 1943-1982. Gut 1988;29:49-56.

9. Hildebrand H, Brydolf M, Holmquist L, Krantz I, Kristiansson B. Incidence and prevalence of inflammatory bowel disease in South-Western Sweden. Acta Paediatr 1994;83:640-5.

10. Ekbom A, Helmick C, Zack M, Adami HO. The epidemiology of inflammatory bowel disease: A large, population-based study in Sweden. Gastroenterology 1991;100:350-8.

11. Monsen U. Inflammatory bowel disease: An epidemiological and genetic study. Acta Chir Scand Suppl 1990;559:1-42.

12. Thomas GAO, Millar-Jones D, Rhodes J, Roberts GM, Williams GT, Mayberry JF. Incidence of Crohn's disease in Cardiff over 60 years: 1986-1990 an update. Eur J Gastroenterol Hepatol 1995;7:401-5.

13. Rose JDR, Roberts GM, Williams G, Mayberry JF, Rhodes J. Cardiff Crohn's disease jubilee: the incidence over 50 years. Gut 1988;24:346-51.

14. Kyle J. Crohn's disease in Northeastern and Northern Isles of Scotland: An epidemiological review. Gastroenterology 1992;103:392-9.

15. Mayberry JF, Rhodes J. Epidemiological aspects of Crohn's disease: a review of the literature. Gut 1984;25:886-99.

16. Mayberry JF, Rhodes J, Newcombe RG. Crohn's disease in Wales, tula associated with CD (personal communication). However, its mechanism of action is unknown. An applicable prospective, double-blind, randomized, placebo controlled clinical trial using a combination of antibiotics such as clarithromycin, clofazimine and rifabutin at sufficient dosages for a period of at least 12 months is suggested as a potentially useful treatment regimen for CD.

Although there is some evidence from molecular medicine that $\mathrm{M}$ paratuberculosis may play a role in the etiology or pathogenesis of $\mathrm{CD}$, this theory remains unproved. This review supports the hypothesis by showing a distinct overlap of some regions reporting high prevalences of $\mathrm{CD}$ and paratuberculosis. It suggests that $\mathrm{M}$ paratuberculosis may be disseminated in these environments, perhaps via drinking water or dairy products, especially milk. This epidemiological review provides justification for further intensive investigation of the proposed hypothesis that $\mathrm{M}$ paratuberculosis plays a role in the etiology of CD.

1967-1976; an epidemiological survey based on hospital admissions. Postgrad Med J 1980;56:336-41.

17. Thomson ABR. The patient with inflammatory bowel disease: Who am I? Can J Gastroenterol 1993;7:42-50.

18. Lashner BA, Kirsner JB. The epidemiology of inflammatory bowel disease: Are we learning anything new? Gastroenterology 1992;103:696-8. (Lett)

19. Probert CSJ, Jayanthi V, Hughes AO, Thompson JR, Wicks ACB, Mayberry JF. Prevalence and family risk of ulcerative colitis and Crohn's disease: an epidemiological study among Europeans and South-Asians in Leicestershire. Gut 1993;34:1547-51.

20. Nanji AA, Denardi FG. Primary adult lactose intolerance protects against development of inflammatory bowel disease. Med Hypotheses 1986;19:1-6.

21. Grange JM. The mycobacteria. In: Parker MT, Collier LH, eds. Topley $\&$ Wilson's Principles of Bacteriology, Virology and Immunity, 8th edn. Systematic Bacteriology, vol 2. Philadelphia: BC Decker, 1990:74-101.

22. Kirschner RA Jr, Parker BC, Falkinham JO III. Epidemiology of infection by nontuberculous mycobacteria. Am Rev Respir Dis 1992;145:271-5.

23. Thayer WR Jr, Chitnavis V. The case for an infectious etiology. Med Clin North Am 1994;78:1233-47.

24. Dukes TW, Glover GJ, Brooks BW, Duncan JR, Swendrowski M. Paratuberculosis in Saiga antelope (Saiga tatarica) and experimental transmission to domestic sheep. J Wildl Dis 1992;28:161-70.

25. Moss MT, Sanderson JD, Tizard MLV, et al. Polymerase chain reaction detection of Mycobacterium paratuberculosis and Mycobacterium avium subsp silvaticum in long term cultures from Crohn's disease and control tissues. Gut 1992;33:1209-13.

26. Cocito C, Gilot P, Coene M, De Kesel M, Poupart P, Vannuffell P. Paratuberculosis. Clin Microbiol Rev 1994;7:328-45.

27. Sanderson JD. Mycobacteria in Crohn's disease. BMJ 1993;306:1131. (Lett)

28. Moss MT, Green EP, Tizard ML, Malik ZP, Hermon-Taylor J. Specific detection of Mycobacterium paratuberculosis by DNA hybridisation with a fragment of the insertion element IS900. Gut 1991;32:395-8.

29. Naber SP. Molecular pathology - Diagnosis of infectious disease. N Engl J Med 1994;331:1212-5.

30. Richter E, Schluter C, Duchrow M, et al. An improved method for the species-specific assessment of mycobacteria in routinely formalin-fixed and paraffin-embedded tissues. J Pathol 1995;175:85-92.

31. Victor T, Jordaan A, du Toit R, Van Helden PD. Laboratory experience and guidelines for avoiding false positive polymerase chain reaction results. Eur J Clin Chem Clin Biochem 1993;31:531-5.

32. Elsaghier A, Prantera C, Moreno C, Ivanyi J. Antibodies to Mycobacterium paratuberculosis-specific protein antigens in Crohn's disease. Clin Exp Immunol 1992;90:503-8. 
33. Sanderson JD, Moss MT, Tizard MLV, Hermon-Taylor J. Mycobacterium paratuberculosis DNA in Crohn's disease tissue. Gut 1992;33:890-6.

34. Dell'Isola B, Poyart C, Goulet O, et al. Detection of Mycobacterium paratuberculosis by polymerase chain reaction in children with Crohn's disease. J Infect Dis 1994;169:449-51.

35. Fidler HM, Thurrell W, McI Johnson N, Rook GAW, McFadden JJ. Specific detection of Mycobacterium paratuberculosis DNA associated with granulomatous tissue in Crohn's disease. Gut 1994;35:506-10.

36. Lisby G, Andersen J, Engbaek K, Binder V. Mycobacterium paratuberculosis in intestinal tissue from patients with Crohn's disease demonstrated by a nested primer polymerase chain reaction. Scand J Gastroenterol 1994;29:923-9.

37. Wu SWP, Pao CC, Chan J, Yen TSB. Lack of mycobacterial DNA in Crohn's disease tissue. Lancet 1991;337:174-5. (Lett)

38. Rosenberg WMC, Bell JI, Jewell DP. Mycobacterium paratuberculosis DNA cannot be detected in Crohn's disease tissues. Gastroenterology 1991;100(Suppl):A611. (Abst)

39. Suenaga K, Yokoyama Y, Okazaki K, Yamamoto Y. Mycobacteria in the intestine of Japanese patients with inflammatory bowel disease. Am J Gastroenterol 1995;90:76-80.

40. Erasmus DL, Victor TC, Van Eeden PJ, Falck V, Van Helden P. Mycobacterium paratuberculosis and Crohn's disease. Gut 1995;36:942. (Lett)

41. Williams ES, Spraker TR, Schoonveld GG. Paratuberculosis (Johne's disease) in bighorn sheep and a Rocky Mountain goat in Colorado. J Wildl Dis 1979;15:221-7.

42. Williams ES, Snyder SP, Martin KL. Pathology of spontaneous and experimental infection of North American wild ruminants with Mycobacterium paratuberculosis. Vet Pathol 1983;20:274-91.

43. Collins MT, Sockett DC, Goodger WJ, Conrad TA, Thomas CB, Carr DJ. Herd prevalence and geographic distribution of, and risk factors for, bovine paratuberculosis in Wisconsin. J Am Vet Med Assoc 1994;204:636-41.

44. Chiodini RJ, Van Kruiningen HJ. The prevalence of paratuberculosis in culled New England cattle. Cornell Vet 1986;76:91-104.

45. Van Kruiningen HJ, Chiodini RJ, Thayer WR, Coutu JA, Merkal RS, Runnels PL. Experimental disease in infant goats induced by a mycobacterium isolated from a patient with Crohn's disease. Dig Dis Sci 1986;31:1351-60.

46. Paling RW, Waghela S, Macowan KJ, Heath BR. The occurrence of infectious diseases in mixed farming of domesticated wild herbivores and livestock in Kenya. II. Bacterial diseases. J Wildl Dis 1988;24:308-16.

47. Taylor AW. Johne's disease - its diagnosis and control. Vet Rec 1951;63:776-85.

48. Merkal RS, Whipple DL, Sacks JM, Snyder GR. Prevalence of Mycobacterium paratuberculosis in ileocecal lymph nodes of cattle culled in the United States. J Am Vet Med Assoc 1987;190:676-80.

49. McNab WB, Meek AH, Duncan JR, Martin SW, Van Dreumel AA. An epidemiological study of paratuberculosis in dairy cattle in Ontario: Study design and prevalence estimates. Can J Vet Res 1991;55:246-51.

50. Kopecky KE. Distribution of bovine paratuberculosis in the United States. J Am Vet Med Assoc 1973;162:787-8.

51. Braun RK, Buergelt CD, Littell RC, Linda SB, Simpson JR. Use of an enzyme-linked immunosorbent assay to estimate prevalence of paratuberculosis on cattle of Florida. J Am Vet Med Assoc 1990;196:1251-4.

52. International Colloquium on Research in Paratuberculosis. Proceedings of the International Colloquium on Research in Paratuberculosis, June 16-18, 1983, Ames, Iowa. Ames: National Animal Disease Center, 1983:16-21.

53. Kopecky KE. Distribution of paratuberculosis in Wisconsin, by soil regions. J Am Vet Med Assoc 1977;170:320-4.

54. Darcel C. Diagnosis of infection with Mycobacterium paratuberculosis. Can Vet J 1995;36:199-200. (Lett)

55. Sonnenberg A, McCarty DJ, Jacobsen SJ. Geographic variation of inflammatory bowel disease within the United States. Gastroenterology 1991;100:143-9.

56. McDiarmid A. Diseases of Free-Living Wild Animals. Rome: Food and Agriculture Organization of the United Nations, 1962:15.
57. Temple RMS, Muscoplat CC, Thoen CO, Himes EM, Johnson DW Observations on diagnostic tests for paratuberculosis in a deer herd. J Am Vet Med Assoc 1979;175:914-5.

58. Power SB, Haagsma J, Smyth DP. Paratuberculosis in farmed red deer (Cervus elaphus) in Ireland. Vet Rec 1993;132:213-6.

59. Fawcett AR, Goddard PJ, McKelvey WA, et al. Johne's disease in a herd of farmed red deer. Vet Rec 1995;136:165-9.

60. de Lisle GW, Collins DM. Johne's disease in red deer. Vet Rec 1995;136:336. (Lett)

61. Soltys MA, Andress CE, Fletch AL. Johne's disease in a moose (Alces alces). Bull Wildl Dis Assoc 1967;3:183-4.

62. Fanning A, Edwards S. Mycobacterium bovis infection in human beings in contact with elk (Cervus elaphus) in Alberta, Canada. Lancet 1991;338:1253-5.

63. Tessaro SV, Forbes LB, Turcotte C. A survey of brucellosis and tuberculosis in bison in and around Wood Buffalo National Park, Canada. Can Vet J 1990;31:174-80.

64. Tessaro SV. The existing and potential importance of brucellosis and tuberculosis in Canadian wildlife: A review. Can Vet J 1986;27:119-24.

65. Tessaro SV, Gates CC, Forbes LB. The brucellosis and tuberculosis status of wood bison in the Mackenzie Bison Sanctuary, Northwest Territories, Canada. Can J Vet Res 1993;57:231-5.

66. Corner AH, Connell R. Brucellosis in bison, elk and moose in Elk Island National Park, Alberta, Canada. Can J Comp Med 1958;22:9-21.

67. Chiodini RJ, Van Kruiningen HJ. Eastern white-tailed deer as a reservoir of ruminant paratuberculosis. J Am Vet Med Assoc 1983;182:168-9.

68. Hermon-Taylor J. Causation of Crohn's disease: The impact of clusters. Gastroenterology 1993;104:643-6.

69. Hole NH. Johne's disease. Adv Vet Sci 1958;4:341-87.

70. Lovell R, Levi M, Francis J. Studies on the survival of Johne's bacilli. J Comp Pathol 1944;54:120-9.

71. Collins CH, Grange JM, Yates MD. Mycobacteria in water. J Appl Bacteriol 1984;57:193-211.

72. von Reyn CF, Waddell RD, Eaton T, et al. Isolation of Mycobacterium avium complex from water in the United States, Finland, Zaire, and Kenya. J Clin Microbiol 1993;31:3227-30.

73. Cryderman A. Trickle down off the land and into the water. Enviroment Views 1994;Spring:15-7.

74. Chiodini RJ, Hermon-Taylor J. The thermal resistance of Mycobacterium paratuberculosis in raw milk under conditions simulating pasteurization. J Vet Diagn Invest 1993;5:629-31.

75. Harrington R Jr, Karlson AG. Destruction of various kinds of mycobacteria in milk by pasteurization. Appl Microbiol 1965;13:494-5.

76. Lupton AA. Some Geographical Aspects of Dairying in Alberta. Edmonton: The University of Alberta Press 1965:77-110. (Thesis)

77. Milk Marketing Board. The Structure of Dairy Farming in England and Wales during 1963/64. London: The Milk Marketing Board, 1965.

78. Finch World Products Series Map \#13: Cattle and Dairying. Chicago: AJ Nystrom \& Co, 1950. (Map)

79. Burk MC, Hammill AE. Milk consumption patterns of a sample of Iowa women. J Am Diet Assoc 1966;49:319-25.

80. Chapman JS, Dyerly M, Spohn S. Epidemiological notes on Mycobacterium kansasii disease. Arch Environ Health 1968;16:673-8.

81. Thayer WR. The use of antimycobacterial agents in Crohn's disease. J Clin Gastroenterol 1992;15:5-7. (Edit)

82. Prantera C, Kohn A, Mangiarotti R, Andreoli A, Luzi C. Antimycobacterial therapy in Crohn's disease: Results of a controlled, double-blind trial with a multiple antibiotic regimen. Am J Gastroenterol 1994;89:513-8.

83. Rastogi N, Seng Goh K, Labrousse V. Activity of clarithromycin compared with those of other drugs against Mycobacterium paratuberculosis and further enhancement of its extracellular and intracellular activities by ethambutol. Antimicrob Agents Chemother 1992;36:2843-6

84. Graham DY, Al-Assi MT, Robinson M. Prolonged remission in Crohn's disease following therapy for Mycobacterium paratuberculosis infection. Gastroenterology 1995;108:A826. (Abst) 


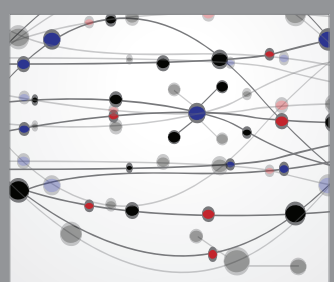

The Scientific World Journal
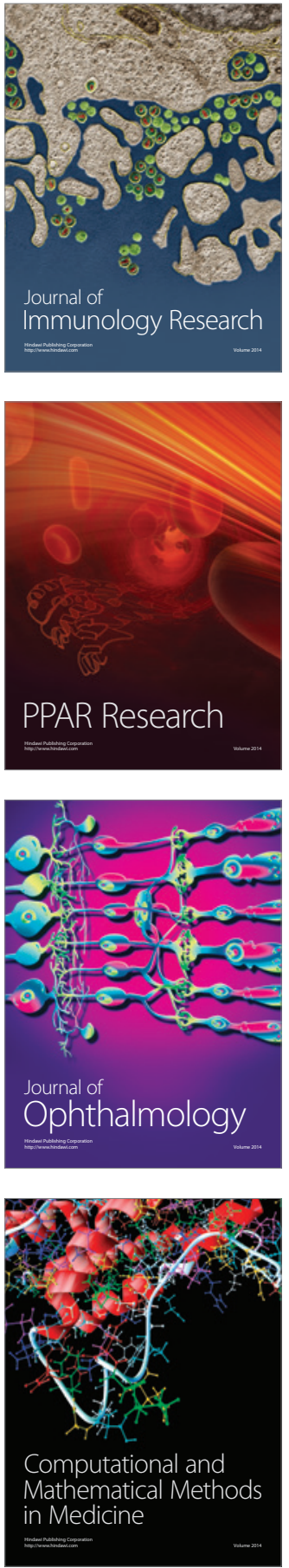

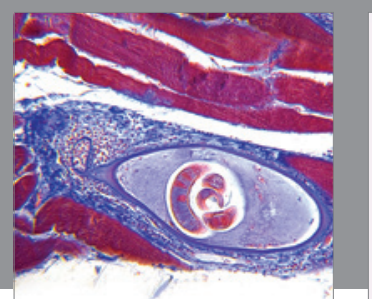

Gastroenterology Research and Practice

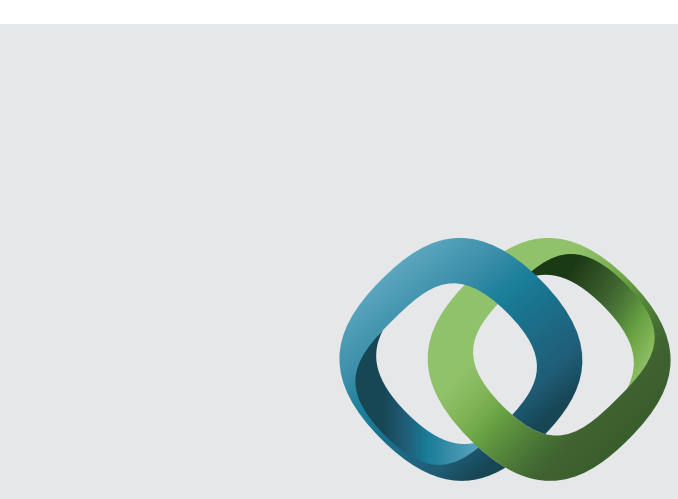

\section{Hindawi}

Submit your manuscripts at

http://www.hindawi.com
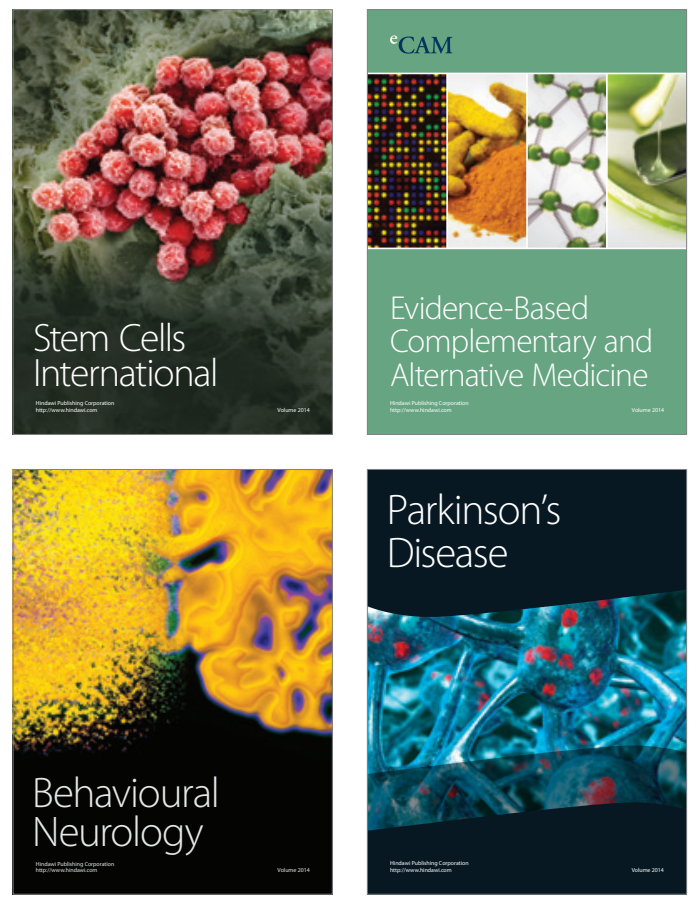
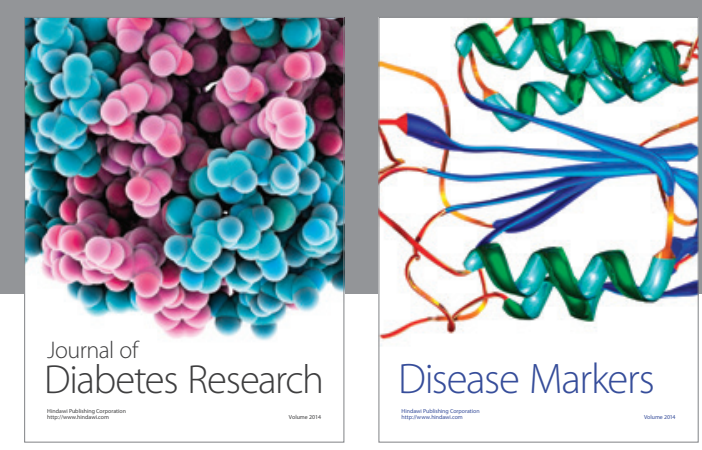

Disease Markers
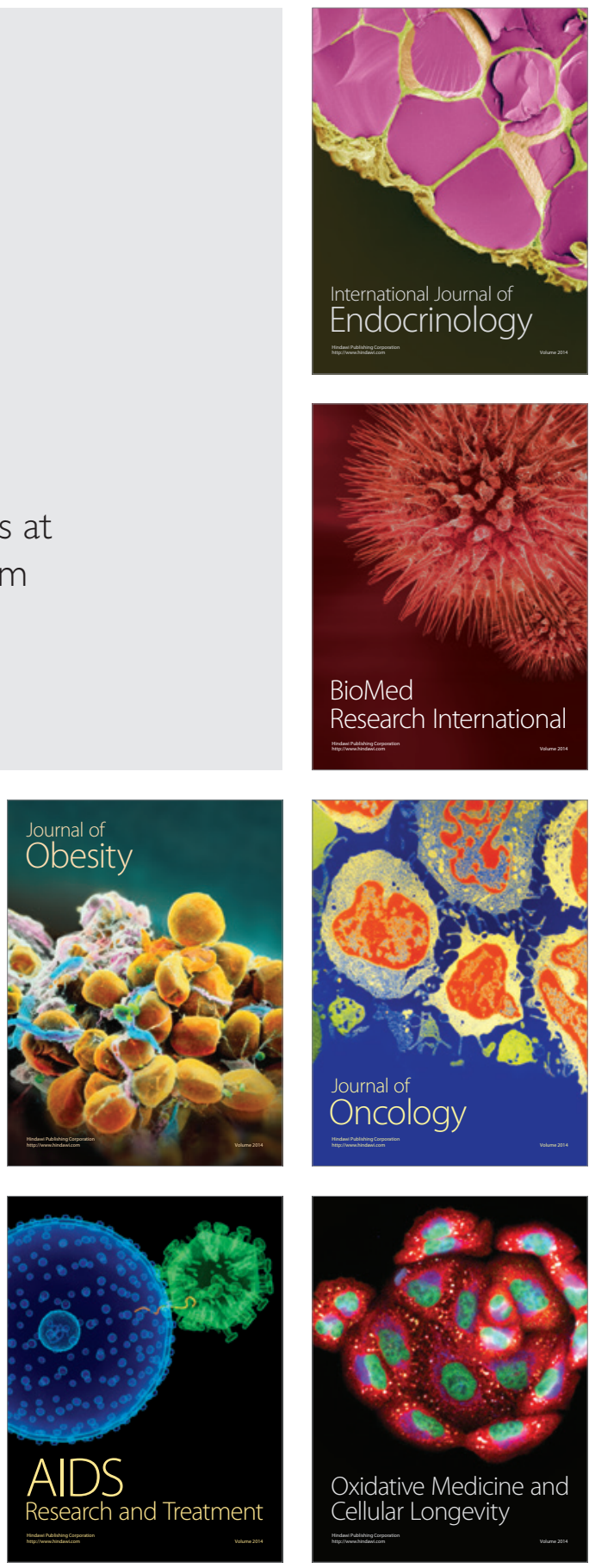